\title{
SPÓJNOŚĆ PLANOWANIA STRATEGICZNEGO ORAZ PLANOWANIA PRZESTRZENNEGO JAKO WARUNEK SPRAWNEGO ZARZĄDZANIA ROZWOJEM MIASTA
}

\section{Abstract \\ Cohesion of Strategic Planning and Spatial Planning as a Condition for Efficient Governance of Urban Development}

The dynamics of processes occurring in urban structures prompts the discussion concerning numerous issues that so far have not decisively contributed to urban development. This paper presents a discussion on the requirement of rational governance of urban space in relation to the need for strategic planning of city development. The subject of considerations is the assessment of the relationship between spatial planning and strategic planning in the context of building the competitiveness of the city. The presented dilemmas around the need to ensure in practice the cohesion between these two types of planning and the described effects of the lack of such cohesion represent a contribution to the debate on contemporary determinants of managing the development of urban structures. Recommendations for public authorities, indicating the need to implement the cohesion of strategic and spatial planning in governance practice, are also presented.

Keywords: urban development, strategic planning, spatial planning.

\section{Streszczenie}

Dynamika procesów zachodzących w miejskich strukturach skłania do podejmowania dyskusji wobec licznych problemów, które do tej pory w decydującym stopniu nie przesądzały o możliwościach rozwoju miasta. W niniejszym artykule została podjęta polemika na temat wymogu racjonalnego zarządzania miejską przestrzenią w odniesieniu do potrzeby planowania strategicznego rozwoju miasta. Przedmiotem rozważań jest ocena relacji zachodzących między planowaniem przestrzennym i planowaniem strategicznym w kontekście budowania konkurencyjności miasta. Zaprezentowane dylematy wokół konieczności zapewnienia w praktyce spójności między obu rodzajami planowania oraz skutków jej braku, stanowią przyczynek do dyskusji na temat współczesnych uwarunkowań sprawnego zarządzania rozwojem struktur miejskich. 
Zostały przedstawione również rekomendacje pod adresem władz publicznych, wskazujące na konieczność wyznawania w praktyce zarządzania zasady spójności planowania strategicznego oraz przestrzennego.

Słowa kluczowe: rozwój miasta, planowanie strategiczne, planowanie przestrzenne.

\section{Wstęp}

Miasta są swoistym wytworem cywilizacji, określoną formą skupiania się ludności w określonej przestrzeni, uwarunkowaną historycznym procesem pogłębiania się społecznego podziału pracy [Ginsbert-Gebert, 1984]. Są to oczywiście skupiska działalności gospodarczej i życia ludzkiego. Ludzie od dawna koncentrowali się w jednostkach osadniczych, ponieważ tylko wspólnym wysiłkiem (zgodnie z ,prawem składania”) mogli zabezpieczać swoje potrzeby, których indywidualnie, albo w małych grupach, zabezpieczyć się nie dawało. To w miastach od czasów rozwoju cywilizacyjnego ludzkości następuje kumulacja wszelkich działań i zjawisk społeczno-ekonomicznych pozwalających na zaspokajanie potrzeb egzystencjalnych i społecznych ludzi. Miasta pełnią ważną rolę w regionach. Jeśli są to ośrodki o względnie dużym potencjale, to w znaczącym stopniu przyczyniają się do rozwoju regionu czy też kraju. Procesy zachodzące w małych miastach także są istotne dla kreowania postępu i rozwoju, jednakże, ze zrozumiałych względów, zakres ich oddziaływania jest mniejszy. Duże ośrodki miejskie są obszarami koncentracji procesów gospodarczych, a w konsekwencji silnie oddziałują na gospodarkę całego kraju, a nawet kontynentu czy świata. Małe miasta, pełniąc również funkcje obsługi ludności wiejskiej, przyczyniają się do upowszechniania nowych form i zasad prowadzenia działalności gospodarczej, wzorców konsumpcji, zachowań, wartości itp. wśród ludności wiejskiej. Można więc przyjąć, iż procesy rozwojowe zachodzące w miastach przekładają się na rozwój społeczno-gospodarczy kraju.

Z tych to względów niezmiernie ważne jest wykorzystywanie w jak najbardziej efektywny sposób zasobów skumulowanych w miastach. Do najważniejszych z nich powszechnie zalicza się przestrzeń wraz z jej zagospodarowaniem. Treści niniejszego artykułu koncentrują się na rozważaniach, czy ze względu na znaczenie właśnie przestrzeni miejskiej dla budowania konkurencyjności miasta i kreowania warunków bytowych planowanie przestrzenne powinno być punktem wyjścia dla planowania rozwoju miasta, czy też w praktyce zarządzania rozwojem miasta powinno mu być podporządkowane. Za jednym albo drugim podejściem przemawiają liczne argumenty. Artykuł ma na celu refleksję nad uwarunkowaniami procesów rozwojowych miasta w kontekście efektywnego gospodarowania przestrzenią. Głównym problemem niniejszej publikacji jest spójność między planowaniem rozwoju miasta a planowaniem przestrzennym. 


\section{Miasto i jego rozwój}

Można przyjąć, że miasto jest organizacją ze swoistym celem działania (zapewnienie jak najkorzystniejszych warunków bytowych oraz budowanie silnej pozycji konkurencyjnej), mającą zasoby służące jego realizacji oraz centrum decyzyjne odpowiedzialne za osiąganie celu. Oczywiście miasto poddawane jest wpływom otoczenia, co ma istotne znaczenie dla procesu podejmowania decyzji dotyczących możliwości wykorzystywania wewnętrznych zasobów, rozwiązywania licznych problemów, wpływania na sprawność zarządzania sprawami miejskimi, przejścia na wyższy poziom trajektorii rozwoju.

W szeregu naukowych koncepcji dotyczących rozwoju miast, opartych na różnych założeniach wyjściowych, tłumaczy się przyczyny rozwoju struktur miejskich. W większości z nich punktem wyjścia do rozważań o przyczynach rozwoju miasta są analiza i ocena sfery aktywności gospodarczej. Zależność ta jest wprost proporcjonalna; bardziej rozwinięta sfera gospodarcza przekłada się na wyższy poziom rozwoju społeczno-gospodarczego miasta. Dobrobyt mieszkańców każdego z krajów zależy w dużej mierze od potencjałów i procesów zachodzących w jego miastach. Miasta to centra wszelakiego postępu, zarówno gospodarczego, jak i społecznego. Rozwój cywilizacji jest wynikiem skumulowania różnorodnych aktywności miejskich społeczności.

Teorie lokalizacji (przegląd teorii lokalizacji zob. Stawasz, 2001: 23-45) tłumaczą zasady wyboru miejsc do prowadzenia działalności przez podmioty gospodarcze i pośrednio wyjaśniają, dlaczego następuje kumulacja aktywności gospodarczej w pewnych obszarach odznaczających się korzystnymi cechami geograficzno-fizycznym oraz innymi walorami wynikającymi z zagospodarowania antropogenicznego. $Z$ tego też względu są one postrzegane jako teorie wskazujące przyczyny rozwoju jednostek osadniczych.

Teoria bazy ekonomicznej w podobny sposób jak teorie lokalizacji tłumaczy przyczyny rozwoju miasta. Rozwój bazy ekonomicznej zapewnia efekty mnożnikowe w postaci rozwinięcia się także pokrewnych sektorów, podwykonawców oraz rynku usług lokalnych i regionalnych [Grosse, 2002: 26; Bury, Markowski, Regulski, 1993: 27].

Rozwój społeczno-gospodarczy w wymiarze przestrzennym jest również tłumaczony poprzez dwa podejścia: „rozwoju od góry” oraz „rozwoju od dołu” [Stawasz, 2001: 30]. Koncepcje rozwoju „od góry” mają swe źródło w polemikach między zwolennikami wzrostu zrównoważonego i niezrównoważonego. W teoriach rozwoju „od góry” przyjmuje się, iż rozwój zostaje zapoczątkowany w nielicznych branżach i miejscach, a następnie, na zasadzie dyfuzji, obejmuje swym zasięgiem pozostałą część rozpatrywanej przestrzeni. W koncepcjach rozwoju „od dołu” kładzie się nacisk na występowanie i wagę inicjatyw oddolnych, wychodzących od społeczności lokalnej, które to inicjatywy przyczyniają się do wykorzystywania zasobów miejscowych, oczywiście przy odpowiednim wsparciu ze strony bardziej rozwiniętych ośrodków. Chodzi tu o wsparcie kadrowe i to gwarantujące pozyskiwanie nowych technik i technologii oraz organizacji. 
W latach osiemdziesiątych XX wieku nastąpiło zespolenie teorii rozwoju „od dołu" z założeniami teorii rozwoju lokalnego (rzadziej określanej jako teoria regionalnego rozwoju endogenicznego). Powszechnie przyjęto, że o rozwoju miasta w dużym stopniu decydują takie przykładowo czynniki jak: jakość zagospodarowania przestrzeni, infrastruktura techniczna i komunikacyjna, struktura społeczna miasta, struktura gospodarki lokalnej. To czynniki ze swej istoty mało mobilne, a ich restrukturyzacja (rozbudowa i modernizacja odpowiadająca potrzebom użytkownikom w przyszłości) wymaga długiego okresu i znacznych nakładów finansowych. $Z$ tego też powodu głównym celem polityki miejskiej winno być jak najlepsze wykorzystanie immobilnych zasobów, tak by zagwarantować pełne zatrudnienie przy możliwie najwyższej produktywności pozostałych czynników wytwórczych [Cappellin, 1991: 10-12].

Teoria produktu podstawowego (jej autorem jest H. Innis), wyjaśnia długookresowe zmiany strukturalne i przyczyny wzrostu ekonomicznego. Warunkiem jest stopniowa specjalizacja produkcyjna, a przede wszystkim skupienie się na wybranej grupie towarów, tych, które mają szansę stać się najbardziej konkurencyjne na rynkach zewnętrznych. Korzyści uzyskiwane są przede wszystkim dzięki obniżaniu kosztów transakcyjnych, doskonaleniu organizacji procesów produkcyjnych oraz podnoszeniu poziomu jakości produktów [Landes, 2000].

Warto również zwrócić uwagę na teorie wpisujące się w nurt ekonomii instytucjonalnej oraz wyjaśnienia procesów rozwojowych formułowane na gruncie kapitalizmu kognitywno-kulturalnego [Sokołowicz, 2015]. Według Scotta, „rozwój gospodarczy zależy w większym stopniu od konkretnych instytucji ekonomicznych i norm społecznych występujących na obszarze regionu (miasta) aniżeli od anonimowych sił wolnego rynku" [Scott, 1993]. Sukces globalnej konkurencji, transformacja lokalnych i regionalnych gospodarek, formowanie się nowych struktur miejskich jest tłumaczone przez paradygmat kapitalizmu kognitywno-kulturalnego. Zgodne jest to z koncepcją trzech obiegów krążenia kapitału, sformułowaną przez Harveya [1978: 101-131]. W podejściu tym inwestycje kapitału w produkcję, nieruchomości oraz reprodukcję siły roboczej są uznawane za podstawowe czynniki miastotwórcze.

Nie wchodząc głębiej w rozważania dotyczące teorii rozwoju miast/regionów, należy przyjąć, że bazują one na uznaniu wewnętrznych zasobów oraz ich dostępności jako podstaw organizowania działalności gospodarczej. Warunkiem niezbędnym kreowania rozwoju miasta jest zdefiniowanie sytuacji, w jakiej się ono aktualnie znajduje. Diagnoza w aspekcie rozpoznania czynników wewnętrznych i zewnętrznych, mających istotny wpływ na zachodzące w nim procesy (oraz, oczywiście, samych procesów) jest punktem wyjścia do myślenia w kategoriach jego rozwoju. Ważnym jest także określenie pozycji konkurencyjnej miasta w odniesieniu do podobnych, ze względu na skalę oraz funkcje, miast regionu, kraju czy też kontynentu. Wewnętrzne zasoby każdego miasta w ujęciu rodzajowym to przykładowo: przestrzeń, prawo, instytucje, mieszkańcy, kapitał społeczny, zagospodarowanie infrastrukturalne, zagospodarowanie i prowadzona aktywność gospodarcza (przemysł, usługi), środowisko przyrodnicze, sfera nauki oraz badań i rozwoju $(\mathrm{B}+\mathrm{R})$, zabytki, obiekty, miejsca tradycji i tożsamości. Bazując 
na wymienionych zasobach oraz możliwościach ich wykorzystywania, a także uwzględniając ich wagę i znaczenie dla dynamizowania procesów rozwojowych, należy formułować założenia polityki rozwoju miasta. Koncepcje rozwoju, budowane na podstawie zasobów miasta, powinny uwzględniać także ich podział na zasoby mobilne i immobilne, ze szczególnym naciskiem na te drugie. Do tej kategorii zalicza się przestrzeń oraz zabytki, obiekty, miejsca tradycji i tożsamości. Przestrzeń miasta odznacza się szczególnymi cechami, a decyzje związane z jej wykorzystaniem na pewne formy zabudowy i funkcje skutkują niemożnością pozyskania jej na inne, co ponadto może wiązać się z koniecznością ponoszenia w długim okresie nieuzasadnionych kosztów związanych z funkcjonowaniem miasta.

\section{Przestrzeń miasta}

Każda aktywność człowieka wymaga miejsca w przestrzeni, a sama przestrzeń jest dobrem ograniczonym. Przy dynamicznym wzroście liczby ludności na świecie, koncentracji społeczeństw w ośrodkach miejskich, wzroście poziomu dobrobytu społecznego, z czym wiąże się także wzrost popytu na różnego rodzaju usługi świadczone na bazie rozbudowywanego systemu urządzeń i obiektów infrastrukturalnych, przy wzroście popytu na tereny budowlane, rekreacyjne, społecznie użyteczne dla różnych grup społecznych, nowe formy zagospodarowania i powierzchnie dla pełnienia dotychczas nierealizowanych funkcji itp., przestrzeń nabiera jeszcze większego znaczenia niż w przeszłości. Oczywiście można rozważać i doprowadzać do wykorzystywania w większym stopniu trzeciego wymiaru przestrzeni - wysokości, ale w wielu krajach/miastach jest to podejście wielce dyskusyjne, o ile w ogóle możliwe, z obiektywnych względów, do zaakceptowania.

Znaczenie przestrzeni miejskiej można rozpatrywać na gruncie ekonomii, przypisując jej określoną wartość. W takim rozumieniu to cecha, która jest podstawą wyceny i wymiany dobra. Ale w przypadku miasta nie tylko w takim znaczeniu należy rozważać wartość miejskiej przestrzeni. Miasto, jako całość, jest własnością wspólną miejskiego społeczeństwa (dobrem publicznym), mimo obowiązywania $\mathrm{w}$ nim prawa własności mieszkańców i organizacji do posiadania majątku (w tym nieruchomości), co w praktyce stanowi istotne ograniczenie dla władz miasta na rzecz organizowania przestrzeni zgodnie z interesem publicznym. Wartość przestrzeni miejskiej powinno się zatem rozpatrywać nie tylko w odniesieniu do kategorii ekonomicznej, ale także z punktu widzenia jej użyteczności, czy też określając jej wartość społeczną (wartość dla pewnej społeczności). Według A. Wallisa, ,przestrzeń społeczna danej zbiorowości stanowi użytkowany i kształtowany przez nią obszar, z którym wiąże ona system wiedzy, wyobrażeń, wartości i reguł zachowania, dzięki którym identyfikuje się najpełniej z tym właśnie obszarem" [Wallis, 1990]. Ważne jest również to, że z punktu widzenia prawa własności wyróżnia się w miastach przestrzeń prywatną i publiczną (powszechnie dostępną). Władze miasta w każdym przypadku mają możliwość oddziaływania 
zarówno na jedną, jak i drugą. Oczywiście w zdecydowanie większym zakresie wpływ ten dotyczy przestrzeni publicznych.

\section{Planowanie przestrzenne a planowanie strategiczne rozwoju miasta}

Warte zastanowienia jest nie tylko określenie, jakie znaczenia dla procesów zachodzących w mieście ma przestrzeń, ale także czy planowania strategicznego rozwoju miasta, które z założenia powinno zostać ukierunkowane na kreowanie dodatniej wartości publicznej', nie należy rozpoczynać się od planowania przestrzennego. I dalej - na ile ważna jest spójność tych dwóch rodzajów planowania w mieście.

Rozważania w tym zakresie należy rozpocząć od zdefiniowania, czym jest rozwój społeczno-gospodarczy miasta i jakie główne czynniki o nim przesądzają. Rozwój oznacza w najprostszym rozumieniu poprawę warunków bytowych oraz wzrost konkurencyjności. Pojęcia „,warunki bytowe” oraz „konkurencyjność” w praktyce nie mają konkretnego rzeczowego odniesienia. Wprawdzie można mierzyć ich poziom, używając wybranych mierników, ale już sam ich dobór ma wymiar subiektywny. Od zastosowanego zbioru miar zależy zatem wynik. Dodatkowo dla różnych grup użytkowników miasta inne cechy będą wpływały na ocenę warunków bytowych czy też na poziom konkurencyjności. Ponadto miasto, jak każda organizacja, może zgodnie z zasadą ekwifinalności wykorzystać różną kombinację zasobów i dojść do tych samych rezultatów. Inaczej rzecz ujmując, organizacja społeczna podobne rezultaty może osiągać na różny sposób.

Przestrzeń (i jej zagospodarowanie) jest w każdym mieście konkretna (to przestrzeń fizyczna, określana zazwyczaj układem ulic, budynków i obiektów, funkcji, form przestrzennych), stanowi zasób miasta, podlega zmianom w sensie przekształcania i wykorzystywania, jest przedmiotem „gry rynkowej”, a formy i struktura jej zagospodarowania mogą generować „skutki zewnętrzne" lub, w ujęciu długookresowym, stanowić barierę rozwoju miasta.

Planowanie strategiczne służy w podstawowym ujęciu podejmowaniu decyzji dotyczących wykorzystywania wewnętrznych i zewnętrznych zasobów, w celu realizacji zadań i przedsięwzięć ukierunkowanych na podnoszenie poziomu warunków bytowych oraz poziomu konkurencyjności. Ponieważ bieżące decyzje zapadają w sytuacji nie do końca rozpoznanej i ocenionej, planowanie strategiczne stwarza szanse na racjonalność, zmniejszenie ryzyka podejmowania decyzji chybionych z punktu widzenia interesu publicznego w ujęciu długookresowym. Niezależnie od tego, jaki ostatecznie przyjmie się skład i układ etapów

${ }^{1}$ Publiczna wartość dodana powstaje wówczas, gdy mieszkaniec, główny interesariusz usług publicznych, a jednocześnie główny ,inwestor” tych usług (także współwłaściciel oraz partner w działaniu), jest usatysfakcjonowany poziomem usług publicznych, co oznacza zaspokojenie jego potrzeb w tym względzie, zob. Rydzewska-Włodarczyk, 2013: 481. 
podejmowania decyzji, w procesie tym podmiotowi decyzyjnemu (władzom miasta) towarzyszy podmiot planowania (zespół, który przeprowadza proces planowania, zespół wewnętrzny lub zewnętrzny organizacji), wykonujący niezbędne operacje myślowe i analityczne na zbiorze informacji odnoszących się zarówno do przedmiotu planowania, jak i jego specyficznego otoczenia. Takie podejście do zagadnień planowania uwzględnia długi horyzont w procesach rozwoju oraz jego kompleksowy charakter. Pozwala na redukowanie zagrożeń i wykorzystywanie szans, jakie znajdują się w otoczeniu. Przyczynia się do ograniczenia czynnika niepewności w procesach funkcjonowania i rozwoju miasta. Pozwala na odejście od zarządzania bieżącego, jako dominującej formy zarządzania w mieście, i podporządkowanie go długofalowym celom, które to z kolei powinny odpowiadać interesowi publicznemu, przy jednoczesnym uwzględnieniu możliwości, a także potrzeb i oczekiwań interesariuszy. Planowanie strategiczne jest procesem ustaleń i uzgodnień, wskazaniem kierunków działań, a formalizuje się poprzez zapis strategii. Strategia rozwoju jest wyrazem zintegrowanego planowania społecznego, gospodarczego, ekologicznego i przestrzennego. W najbardziej ogólnym ujęciu oznacza sposób osiągania wyznaczonych celów przez sterowanie rozwojem. Strategia rozwoju społecznego i gospodarczego miasta jest formułą formalnego i nieformalnego porozumienia między użytkownikami miejskiej przestrzeni, którzy są zainteresowani kierunkami rozwoju, wyrażają wolę działania na rzecz uzgodnionych celów programowych i przyjmują na siebie realizacje wyznaczonych im działalności. W takim rozumieniu planowania strategicznego należy uznać jego nadrzędność nad planowaniem zagospodarowania przestrzennego. W ujęciu teoretycznym takie stanowisko jest w pełni uzasadnione. Potwierdza to fakt, iż planowanie strategiczne rozpoczyna się od rozpoznania zasobów (i ich atutów) mogących stanowić podstawę do wskazania kierunków i celów rozwoju. Diagnoza jest punktem wyjścia do formułowania założeń strategii rozwoju miasta. Oczywiście, co wynika z metodyki planowania strategicznego, ważne jest również rozpoznanie zmian i procesów możliwych do zaistnienia w otoczeniu miasta.

Planowanie strategiczne w praktyce jest odpowiedzią na pytanie, jakie funkcje będą w mieście realizowane (w podziale na dochodotwórcze i obsługowe), jak będzie zagospodarowana przestrzeń, i czy procesy zmian i przekształceń różnych miejskich struktur będą odpowiednie nie tylko dla wymogów i potrzeb społeczeństwa żyjącego obecnie, ale przede wszystkim przyszłych pokoleń. Do tego potrzebna jest koncepcyjna wizja miasta w przyszłości w odniesieniu do postępu techniczno-technologicznego (np. technologie OZE, Internet), aspiracji społeczeństwa (np. duże mieszkania, atrakcyjna przestrzeń publiczna, rozwinięta komunikacja publiczna), potrzeb inwestorów (np. powierzchnie biurowe, przemysłowe, logistyczne), kosztów funkcjonowania miasta (np. zwarta albo rozproszona zabudowa, utrzymanie terenów zielonych, czystości w miejscach publicznych). Ze względu na szeroko rozumiany postęp, inne będą przesłanki dla wykorzystywania miejskiej przestrzeni. Tak więc zmienią się:

- oczekiwania podmiotów gospodarczych poszukujących miejsca lokalizacji dla prowadzenia działalności gospodarczej,

- preferencje deweloperów działających na rynku mieszkaniowym, 
- wymogi co do lokalizacji obiektów infrastruktury technicznej i użyteczności publicznej,

- potrzeby mieszkańców o określonym systemie wartości i poczuciu estetyki odnośnie do miejsca zamieszkania i atrakcyjności przestrzeni publicznej,

- wymogi odnośnie do dostępności komunikacyjnej, otwartości przestrzeni, warunkującej możliwość szybkiego przemieszczania się i swobodnego korzystania z różnych funkcji realizowanych w mieście,

- zasady odnośnie do konieczności rewitalizacji centów i ograniczania niekontrolowanego rozlewania się miasta.

Niemniej znaczenie przestrzeni i form zagospodarowania antropogenicznego dla rozwoju miasta, mimo postępu techniczno-technologicznego, nie zmieni się, a właściwie można założyć, że będzie jeszcze większe. Wynika to z faktu, iż niezagospodarowanych przestrzeni w mieście będzie coraz mniej, a istniejące zagospodarowanie często wraz z upływem czasu wymagać będzie szeroko rozumianej modernizacji. $Z$ tych powodów gospodarowanie immobilnym i ograniczonym zasobem musi być głęboko przemyślane i racjonalne. Stwierdzenie to skłania do uznania, iż planowanie dotyczące wykorzystywania przestrzeni w miastach powinno być punktem wyjścia do określenia wizji jego rozwoju. Tylko takie podejście stwarza szanse na zapewnienie spójności między planowaniem strategicznym i planowaniem przestrzennym.

Planowanie zagospodarowania przestrzennego, rozumiane jako podejmowanie decyzji co do przeznaczenia i rodzaju użyteczności miejskiej przestrzeni, jest zadaniem realizowanym przez urbanistów przestrzennych. Opracowywany przez nich dokument pod nazwą plan przestrzennego zagospodarowania jest narzędziem zarządzania przestrzenią w mieście. To od władz miasta powinny wypłynąć sugestie dotyczące polityki przestrzennej. Umiejętność określania przez władze miasta potrzeb odnośnie do zapotrzebowania różnych grup mieszkańców, inwestorów, organizacji publicznych itp. na przestrzeń jest jednym z warunków poprawności gospodarowania nią.

Można za Markowskim [2002] postawić tezę, że w globalizującym się świecie, występuje elastyczność systemów produkcji i systemy te wymagają elastycznych struktur zagospodarowania przestrzennego. Przy obecnych sposobie organizacji i strukturze produkcji nie jest specjalnie ważna odległość od rynków zbytu, ale wielkość tegoż rynku i jego kumulacja. Z pewnością istnieje więc specyficzna zależność między formą zagospodarowania przestrzennego (w tym dostępnością komunikacyjną, możliwością zagospodarowania terenów na cele produkcyjne) a rozwojem gospodarczym. Tego rodzaju zależności należy uwzględnić zarówno formułując strategię rozwoju społeczno-gospodarczego miasta, jak i w założeniach planów zagospodarowania. I dalej: preferencje lokalizacyjne podmiotów gospodarczych to wybór miejsc dla nich najkorzystniejszych z ekonomicznego punktu widzenia, co często skutkuje zawłaszczaniem lokalnych zasobów oraz generowaniem negatywnych skutków zewnętrznych. W tym przypadku zadaniem władz publicznych jest ochrona przed ewentualnymi, negatywnymi następstwami działalności tychże podmiotów. Najważniejszym instrumentem w tym względzie jest planowanie przestrzenne, które stwarza szanse na kontrolowanie skutków 
zewnętrznych. A to z kolei przemawia na korzyść planowania przestrzennego w odniesieniu do planowania strategicznego.

\section{Zakończenie}

Zgodnie z obowiązującymi obecnie trendami, współczesne miasta powinny być projektowane zgodnie z rosnącym zrozumieniem dla „idei miasta dla ludzi” [Gehl, 2014]. Miasto XXI wieku odznacza się silną gospodarką oraz zróżnicowanymi funkcjami, jest miejscem intensywnego życia, o wysokiej jakości przestrzeni publicznych, które sprzyjają budowaniu tożsamości miejskiej społeczności. Uznając, że rozwój jest procesem o charakterze zarówno ilościowym (wymiar ekonomiczny), jak i jakościowym (wymiar społeczny), w praktyce zarządzania rozwojem miasta powinno się uwzględniać perspektywę długiego trwania, czyli wpływ na środowisko (wymiar przestrzenny i środowiskowy) [Turała, 2015: 11]. Efektywność działań w tym względzie należy kojarzyć z umiejętnością wykorzystywania podejścia zintegrowanego, polegającego na uwzględnieniu zależności między sferą gospodarczą, społeczną i przestrzenno-środowiskową.

Podsumowując zaprezentowane rozważania, można sformułować następujące wnioski:

- postęp techniczno-technologiczny, zmiany w zakresie terytorialnej organizacji działalności przemysłowej i usługowej, oraz wzrost poziomu zamożności społeczności miejskich przekładają się na konieczność pozyskiwania przestrzeni pod nowe formy zagospodarowania, odpowiadające współczesnym i przyszłym potrzebom miejskich użytkowników,

- przestrzeń i formy jej zagospodarowania są najcenniejszym zasobem w mieście, i z tego też względu racjonalne gospodarowanie przestrzenią (zgodne z interesem publicznym) stanowi wyzwanie dla władz miasta,

- planowanie strategiczne rozwoju społeczno-gospodarczego miasta powinno, jako jeden z priorytetów, uwzględniać wymóg ochrony przestrzeni przed jej zawłaszczaniem na rzecz partykularnych interesów, co oczywiście stoi w sprzeczności z interesem publicznym,

- planowanie przestrzenne w swych założeniach co do wykorzystywania przestrzeni powinno uwzględniać określone przez władze miasta wizje i kierunki rozwoju oraz uwzględniać preferencje mieszkańców co do wykorzystywania miejskiej przestrzeni,

- planowanie strategiczne powinno wskazywać kierunki rozwoju gospodarczego miasta, a następnie kierunki te powinny stanowić podstawę do dokonywania $\mathrm{w}$ procesie planowania przestrzennego wyborów odnośnie do wykorzystywania przestrzeni na przyszłościowe funkcje,

- planowanie przestrzenne powinno zapobiegać konfliktom społecznym na tle przestrzennym, bo takie konflikty zawsze generują nieuzasadnione koszty. 


\section{Bibliografia}

Bury P., Markowski T., Regulski J. (1993), Podstawy ekonomiki miasta, Fundacja Rozwoju Przedsiębiorczości, Łódź.

Cappellin R., Patterns and Policies of Regional Economic Development and the Cohesion among the Regions of the European Community, referat wygłoszony podczas konferencji w Karsruhe, sierpień 1991, cyt. za: J. Chmiel, Małe i średnie przedsiębiorstwa a rozwój regionów, Zakład Badań Statystyczno-Ekonomicznych GUS i PAN, Warszawa 1997, s. 80 .

Gehl J. (2014), Miasta dla ludzi, Wydawnictwo RAM, Kraków.

Ginsbert-Gebert A. (1984), Polityka komunalna, PWE, Warszawa.

Chmiel J. (1997), Małe i średnie przedsiębiorstwa a rozwój regionów, Zakład Badań Statystyczno-Ekonomicznych GUS i PAN, Warszawa.

Grosse T.G. (2002), Przegląd koncepcji teoretycznych rozwoju regionalnego, „Studia Regionalne i Lokalne", nr 1(8).

Harvey D. (1978), The Urban Process Under Capitalism: A Framework for Analysis, „International Journal of Urban and Regional Research", no. 2(1-4), za: M. Błaszczyk, Rozwój miasta postfordowskiego w kontekście teorii obiegu kapitału [w:] Współczesne czynniki i bariery rozwoju miasta, pod red. A. Wolaniuka, Wydawnictwo Uniwersytetu Łódzkiego, Łódź 2015, s. 48.

Landes D.S. (2002), Bogactwo i nędza narodów. Dlaczego jedni są tak bogaci, inni tak ubo$d z y$, Muza SA, Warszawa, za: T.G. Grosse, Przeglad koncepcji teoretycznych rozwoju regionalnego, „Studia Regionalne i Lokalne” 2002, nr 1(8), s. 27.

Majer A. (2014), Odrodzenie miast, Wydawnictwo Uniwersytetu Łódzkiego, Wydawnictwo Naukowe Scholar, Łódź-Warszawa.

Markowski T. (2002), Globalizacja i metropolie, teoria i rzeczywistość [w:] Studia z zakresu zarządzania publicznego, Materiały seminarium naukowego, t. II, pod red. J. Hausnera, M. Kukiełki, Akademia Ekonomiczna w Krakowie, Kraków, s. 204-205.

Ratajczak M. (2015), Wprowadzenie do teorii kapitalizmu kognitywnego: kapitalizm kognitywny jako reżim akumulacji, „Praktyka Teoretyczna”, nr 1(15).

Rydzewska-Włodarczyk M. (2013), Teoretyczne aspekty pomiaru wartości publicznej jednostek samorzadu terytorialnego, Prace Naukowe Uniwersytetu Ekonomicznego we Wrocławiu, nr 291.

Scott A.J. (1993), Technopolis. High-Technology Industry and Regional Development in Southern California, University of California Press, Berkeley, CA, za: T.G. Grosse, Przeglad koncepcji teoretycznych rozwoju regionalnego, ,Studia Regionalne i Lokalne” 2002, nr $1(8)$, s. 39.

Sokołowicz M. (2015), Rozwój terytorialny w świetle dorobku ekonomii instytucjonalnej. Przestrzeń - bliskość - instytucje, Wydawnictwo Uniwersytetu Łódzkiego, Łódź.

Stawasz D. (2001), Współczesne uwarunkowania rozwoju polskich regionów, Wydawnictwo Uniwersytetu Łódzkiego, Łódź.

Studia z zakresu zarządzania publicznego, Materiały seminarium naukowego (2002), t. II, pod red. J. Hausnera, M. Kukiełki, Akademia Ekonomiczna w Krakowie, Kraków. 
Turała M. (2015), Planowanie jako instrument zintegrowanego zarzadzania $w$ jednostkach samorzadu terytorialnego, Katedra Zarządzania Miastem i Regionem WZ UŁ, Łódź.

Wallis A. (1990), Socjologia przestrzeni, Niezależna Oficyna Wydawnicza, Warszawa.

Współczesne czynniki i bariery rozwoju miasta (2015), pod red. A. Wolaniuka, Wydawnictwo Uniwersytetu Łódzkiego, Łódź.

Vercellone C. (2016), Kapitalizm kognitywny a modele relacji płac: czego nauczyl nas francuski ruch przeciwko umowom o pierwsza prace (anty-CPE), za: http://www.ha.art.pl/ prezentacje/39-edufactory/1719-carlo-vercellone-kapitalizm-kognitywny-a-modele-regulacji-relacji-plac.html [dostęp: 20.06.2016]. 